\title{
HYPOCRISY AND MORAL AUTHORITY
}

\author{
Jessica Isserow and Colin Klein
}

$\prod \rrbracket$

YPOCRITES INVITE MORAL OPPROBRIUM, and charges of hypocrisy are a significant and widespread feature of our moral lives. Yet it remains

unclear what hypocrites have in common, or what is distinctively bad about them. We propose that hypocrites are persons who have undermined their claim to moral authority. Since this self-undermining can occur in a number of ways, our account construes hypocrisy as multiply realizable. As we explain, a person's moral authority refers to a kind of standing that they occupy within a particular moral community. This status is both socially important and normatively precarious. Hence, moral agents are right to be vigilant when it comes to hypocrisy, and are often justified in their outrage when they detect it. We further argue that our view can preserve what is attractive in rival accounts, while avoiding their associated problems.

\section{INTRODUCTION}

Everyone has been outraged by a hypocrite. Perhaps it was a moralistic vegan friend who managed to sneak the occasional steak. Maybe it was a coworker whose proselytizing piety did not keep them from sleeping in on Sundays. Or perhaps it was a friendly neighbor, a self-advertised keen and green recycler who (you couldn't help but notice) was consistently too lazy to separate plastic from cardboard. Each looks like a hypocrite, especially to the uncharitable eye. Yet what (if anything) do they all have in common?

One obvious and distinctive feature that hypocrites seem to share is a kind of mismatch between their pronouncements and their actions. ${ }^{1}$ The hypocrite, we tend to think, is someone who says one thing but does another. Yet this cannot be the whole story. Mismatches between our words and our actions are common enough; most of us are occasionally inconsistent. We often change our

1 Szabados and Soifer, "Hypocrisy, Change of Mind, and Weakness of Will," 61; McKinnon, "Hypocrisy and the Good of Character Possession," 716; Wallace, "Hypocrisy, Moral Address, and the Equal Standing of Persons," 308. 
perspectives on moral issues over time. And sometimes we simply succumb to weakness of will, shamefully scoffing down that chocolate mud cake after weeks of touting the health benefits of the Atkins Diet. ${ }^{2}$ So mere mismatches cannot suffice to single out the phenomenon of hypocrisy. The hypocrite's failure seems to differ in kind from these other forms of inconsistency_-not just in degree.

What exactly are hypocrites, then? The question is worth asking. Judgments of hypocrisy play an important and widespread role in our moral lives. Public figures are the most obvious cases: lapsed politicians and Tartuffian priests are common targets of hypocrisy judgments. But private individuals are equally eligible. The vegetarian roommate caught sneaking bacon or the philandering friend who condemns adultery are no less hypocritical than those in the public eye. Nor are judgments of hypocrisy restricted to individuals. The United States is frequently accused of hypocrisy with respect to foreign policy or domestic surveillance. Given the importance and breadth of the phenomenon, it deserves an adequate account.

Getting clear on hypocrisy is also a morally important project. The ascription of hypocrisy is a serious charge. Hypocrites tend to invite moral opprobriumwe condemn them, and usually quite harshly. ${ }^{3}$ One would hope that this moral censure is warranted. It would be disquieting if, on reflection, hypocrites turned out to be guilty of some relatively minor wrong. If so, we ourselves may have subjected them to disproportionate moral sanction. ${ }^{4}$

Yet it is far from obvious just what the hypocrite's distinctive failure is. Some hypocrites deceive, and some manipulate. However, it would be surprising if they were merely guilty of those vices. If hypocrites were just liars, we would need no special category to condemn them - we already condemn liars. Similar-

2 As these examples suggest, hypocrisy is structurally similar to change of mind and weakness of will. Some might even suspect that our failed Atkins dieter is a hypocrite. (Though this is likely to depend on how they fill in the details of the case.) Teasing apart hypocrisy from other, closely related phenomena is a worthwhile project; indeed, it seems that weakness of will is often invoked as an alternative defense against a charge of hypocrisy. Sorting out that relation outstrips our project here, but for promising attempts, see McKinnon, "Hypocrisy and the Good of Character Possession," and Szabados and Soifer, "Hypocrisy, Change of Mind, and Weakness of Will."

3 Following Szabados, "hypocrite" seems to be "a well-established term of moral condemnation" ("Hypocrisy," 202). Hypocrisy is at the very least something typically "viewed with repugnance" (Statman, "Hypocrisy and Self-Deception," 57). Indeed, some go so far as to describe it as "the only unforgivable sin" (Shklar, "Let Us Not Be Hypocritical," 1). That hypocrites are traditionally met with disdain comes as no surprise. Dante (literally) had a special place in hell for them.

4 On this issue, see Statman ("Hypocrisy and Self-Deception"), who suggests that hypocrisy does not always warrant the extreme moral censure that it invites. 
ly, we find various kinds of manipulation bad quite on their own. An adequate account of hypocrisy can therefore shed some much-needed light on the apparent normative significance of this category: what exactly is the moral failure of which hypocrites are guilty, and why is this something that we should want to keep track of?

In this paper, we develop an account of hypocrisy that vindicates the idea that hypocrites form a distinct moral category, supports the intuition that they typically deserve moral censure, and illuminates the important social roles that hypocrisy attributions play in our moral lives. Specifically, we argue that hypocrites are persons who have, by mismatch between judgments and actions, undermined their claim to moral authority, where (very roughly), a person's moral authority is understood as a kind of standing that they occupy within a particular moral community - a status that is intimately tied up with their capacity to (1) warrant esteem, and (2) bestow (dis)esteem on others. Since an agent can undermine their moral authority in many ways, our account construes hypocrisy as multiply realizable.

Two features of our discussion are worth noting from the outset. First, our explanatory target is the hypocrite - that is, one who is guilty of hypocrisy. However, we do not assume here that hypocrisy amounts to a full-fledged character trait, or even to a particularly strong disposition. Perhaps it might in fiction, but Tartuffe is, we take it, something of a limiting case. As far as our day-to-day moral evaluations go, we seem perfectly able (and indeed, perfectly willing) to condemn someone as a hypocrite following just one instance of hypocrisy on their part. If charges of hypocrisy were ascriptions of some more robust character trait, then it is puzzling why we see fit to levy these charges without evidence of a more consistent pattern of behavior. ${ }^{5}$ Many accounts have, we suggest, gone astray by assuming that hypocrisy amounts to a kind of settled disposition. Not all hypocrites exhibit the robust scheming dispositions of Tartuffe or Uriah Heep. To assume as much is to risk offering a caricature of hypocrisy—not something that can shed much light on the normative significance of the phenomenon as it operates in everyday life.

Second, our explanatory project is paradigm-based. Our strategy will be to first identify (what we take to be) exemplars of hypocrisy-pious priests who are secretly corrupt, homophobic senators whose private dalliances conflict

5 It is possible that "hypocrite," like "liar," is ambiguous between (1) an individual who is guilty of hypocrisy (or lying) and (2) an individual with a strong disposition to be hypocritical (or to lie). As we argue, the former understanding seems closer to the term "hypocrite" as it functions within ordinary usage. Since our discussion centers on everyday attributions of hypocrisy, we take (1) to be a more fitting candidate for our explanandum. 
with their explicit disavowals, and the like. After having pinned down the explanatorily basic features of these paradigm cases, we develop an account of hypocrisy that can accommodate them. We then argue that more common or garden instances of hypocrisy can fruitfully be understood in similar terms. ${ }^{6}$ The core features that we find in paradigmatic instances of hypocrisy are, we suggest, present in more banal cases as well, though they are present to varying degrees, and in less obvious and pronounced ways.

The road ahead is as follows. We begin by introducing the basic idea of a moral authority, explaining the important roles that moral authorities play in the broader community (section 2 ). We then turn our attention to paradigmatic instances of hypocrisy (section 3 ). Our considered hypothesis will be that paradigmatic hypocrites are best understood as individuals who have, by their actions, undermined their claim to acting as a moral authority. We then explain how other instances of hypocrisy - those which are less clear-cut, or non-paradigmaticcan fruitfully be understood in these terms as well. Following that, we argue that our account fares better than its rivals along a number of dimensions (section 4). Our proposal is particularly helpful in supplying a general framework that incorporates the insights of these other views while also diagnosing where they go astray. Finally, and as we explain, our account sheds some much-needed light on the important social roles that judgments of hypocrisy play within and across contemporary moral communities (section 5). In particular, we suggest that charges of hypocrisy offer morally homogeneous communities some degree of protection, and moderate tensions within heterogeneous ones.

\section{MORAL AUTHORITY}

Central to our account of hypocrisy is the notion of a moral authority. An individual's moral authority refers to a certain kind of social status that they enjoy within a particular moral community. As we now explain, moral authorities are prevalent within society, and they serve a range of important functions in moral life.

6 Our investigative strategy is similar to that of Miranda Fricker, who has recently developed a paradigm-based account of blame ("What's the Point of Blame? A Paradigm Based Explanation"). Following Fricker, we think that there is much to be gained from pursuing a paradigm-based explanation for multifaceted and diverse phenomena, which tend to elude simple and straightforward analysis. Our approach also bears some similarities to Aristotle's discussion of "being." On G.E.L. Owen's well-known interpretation, Aristotle takes "being" to have a "focal meaning," which serves as the explanatory basis for its many different senses ("Logic and Metaphysics in Some Earlier Works of Aristotle"). We thank an anonymous referee for pointing this out. 


\subsection{The Basic Idea}

Suppose I am faced with a difficult moral decision, such that I am genuinely uncertain how to act. A natural move would be to turn to others for help. I might ask for advice. Or, I might simply examine how others act in similar situations. Some will be more suited to this role than others. The judgments and actions of my peers, for example, are of mixed utility. It is good to know what my neighbors do, but they might be wrong. (This is especially pressing if, say, my conundrum involves the possibility that I am complicit in a widespread injustice.) What would be far more helpful would be to look to someone whom I considered especially trustworthy in these matters. If I were religious, an obvious choice would be a priest. But I might equally well turn to a wise grandparent, a popular friend, or an experienced colleague. Or I might look further afield, to the judgments and actions of politicians, inspirational speakers, televangelists, or popes.

Call someone who plays this special role a moral authority. In paradigmatic cases, a moral authority is someone whose moral pronouncements a community takes especially seriously. We look up to moral authorities, and we turn to them for moral guidance. We try to refrain from the sort of behavior that they condemn, and to become the kind of persons to whom they lend praise. Moral authorities are invested with this special status (in part) because they are thought to be especially good at living a decent moral life. And their moral assessments matter more than most; because others look to them for guidance as well, their judgments usually have more direct and tangible consequences on how we are judged within the relevant community.

\subsection{The Role of Moral Authority}

Moral authorities, we submit, have practical rather than just epistemic authority. We take the advice or criticism of moral authorities to be pro tanto action-guiding — not merely a reliable source of information regarding our moral duties. In this sense, moral authorities serve an analogous function to political authorities. Specifically, they play three important roles, parallel to the three traditional roles of political authorities: making laws, adjudicating whether laws have been broken, and meting out punishment and reward. ${ }^{7}$

The third parallel is the most obvious. Paradigmatic moral authorities (e.g., judges, medieval priests) often have direct access to the traditional tools of coercion provided by the state. Such power gives their moral judgments special bite. Yet this feature is neither necessary nor even especially common. Most moral authorities simply wield the powerful sanctioning tool of moral disapproval. 
Blame and resentment are, we assume, social punishments in their own right. Moral criticism can operate in a similar way as legal sanctions, and have parallel effects on agents' behavior. ${ }^{8}$

The sanctioning power of a moral authority is amplified in several ways by their standing within the relevant community. Because moral authorities are held in high regard, people who look up to them tend to emulate their patterns of disapproval. So their criticisms cannot simply be ignored in the way that we might shrug off the judgment of a less worthy peer. This is not to say that a moral authority need condemn us from the pulpit. Indeed, in many cases they need not know us at all: the brimstone preacher who condemns dancing may not even know me. What is important is that through their sermons my community will come to look askance at all who step into dancehalls, including me.

While enforcement is the most obvious parallel with political authorities, moral authorities also serve the other two functions. We sometimes look to moral authorities to adjudicate in edge cases. I accept that dancing is sinfulbut what about a first dance at a wedding? I know fraud is intolerable-but is it wrong to sell my textbook evaluation copies to the shifty guy who makes the rounds every semester? One's peers may well differ on whether these count as transgressions. If so, it is commonplace to seek out a more trusted person for advice and counsel.

Note that the adjudicative function of moral authority really has two roots. For one, moral authorities are taken to be particularly good judges of the right thing to do: one reason they have an esteemed function is that they seem to get things right. It is worth emphasizing, however, that their authority is not merely reducible to good judgment. Moral authorities are thought to be especially good at living a morally decent life. Theoretical knowledge of the moral facts clearly is not sufficient for doing so. ${ }^{9}$ Moreover, such knowledge would seem to be poor grounds for investing someone with practical authority; following Estlund, one ought to be wary of confusing experts with bosses. ${ }^{10}$ Thus, moral authorities are not simply epistemic authorities. That said, they occupy a trusted position, and so they do have a correspondingly greater responsibility to get things right. If they lack the knowledge or skill, then they ought to have backed down, lest they lead others astray. candidates for moral experts) are no more likely to act in accordance with their explicit moral views than professors in other fields. Schwitzgebel and Rust, "The Moral Behavior of Ethicists." 
For another, we might ask moral authorities to adjudicate precisely because of their sanctioning power. I may ask my department chair about selling my sample textbooks partly because I trust their judgment and partly because they are the one who would decide whether I have overstepped the bounds of propriety. On a smaller scale, we might turn to moral authorities simply because they provide us with evidence of the punitive responses that await our moral transgressions. My environmentally conscious friend may not be the CEO of Greenpeace, but they claim far more authority with respect to environmental issues than anyone else within my close circle. So it is useful to turn to them for advice in these matters - doing so renders me less vulnerable to others' judging eyes.

Finally, moral authorities can play something like a law-giving role. This is not to suggest that they literally construct or determine the moral facts (a suggestion at which many would balk). It is only to suggest that they plausibly play an important role in determining what a particular group of agents takes those facts to be. It is wrong to use racial slurs. But which speech acts count as slurs is often up in the air, and moral leaders can play an important role in making sure that everyone is on the same page. Similarly so for facts about the severity of a transgression. Everyone agrees that sexual harassment is bad, but respected members of a philosophy department (say) play an important role in determining whether others treat harassment as trivial or grave. In many cases, the adjudicative and the law-giving shade into one another, but both aspects are important.

\subsection{The Elevation of Moral Authority}

According to our story, a moral authority's considered judgments are taken to be action-guiding because they have come to occupy a special standing within a particular moral community. But we have said very little about how moral authorities get elevated-just how do they earn their moral street credit? This is a complex social question. Perhaps some are born to authority, some achieve it, and some have moral authority thrust upon them.

We suspect that the second is most common; typically, moral authorities earn their status through an active investment in moral issues. For the most part, such persons exhibit their investment by moralizing - through moral criticism, deliverances of praise and blame, and the like. Doing so earns them a special status for a number of reasons.

First, moralizing is itself a morally valenced action, and so worthy of esteem in its own right. The whistle-blower who condemns injustice at great personal cost is worthy of esteem not (just) because they made the right judgment, but because the action of moralizing was itself a difficult one. This is even so when moralizing takes the form of praise or blame: both require effort, expend 
some degree of social capital, and expose us to criticism and resentment in turn. Punishment thus comes at a cost, and large communities can only form if some are willing to take on that burden. ${ }^{11}$ Most of us free ride on the moralizing of others, so we tend to admire those who do the work and take on the associated risks.

Second, an important link is typically taken to hold between practice and preaching. Ceteris paribus, we assume that a person's moral pronouncements reflect their dispositions - that they are disposed to perform those acts to which they lend praise, and to refrain from the sorts of behavior that they criticize. This is not merely a feature of paradigmatic moral leaders. For the most part, we presume that there are "certain minimal connections" between people's professed judgments and their "desires, intentions, and actions." ${ }^{12}$ We take a religious friend's praising chastity, for example, as evidence that they are likely (or at least more likely than a randomly chosen person) to be someone who is motivated to refrain from a life of $\sin .^{13}$

It is worth addressing some potential concerns before proceeding. First, although the idea seems intuitive enough, one might wonder why exactly our moral words are typically taken to have implications for our behavior. While fully addressing this question is well beyond the scope of this paper, we suspect that the presumed connection here is, in large part, owing to conversational norms. As Wallace suggests, there seems to be a foundational conversational assumption underlying much of our moral intercourse "that our interlocutors would not put forward criticism of other people if they lacked the standing or entitlement to do so." ${ }^{14}$ It is important here to distinguish two senses of "criticism": (1) the expression of a negative moral opinion, and (2) an act of condemnation. ${ }^{15}$ On the latter understanding (with which we are concerned here), criticism is a kind of speech act that an agent must be in a position to perform. When we declare that we are "not in a position" to criticize others, we refer to some kind of "disabling fact" about ourselves that undermines the illocutionary force of our utterance. And one prime candidate for such a disabling fact would surely be that we ourselves are guilty of the relevant vice. It is for this reason that an agent who

See Boyd et al., "The Evolution of Altruistic Punishment.”

McKinnon, "Hypocrisy, with a Note on Integrity," 327.

This is not to assume the truth of "motivational internalism" - that is, an especially tight conceptual connection between moral judgment and motivation. We only assume that people's moral judgments tend to shape their behavior in important ways. This seems plausible; moral judgments certainly do not appear to be epiphenomenal.

Wallace, "Hypocrisy, Moral Address, and the Equal Standing of Persons," 317.

Cohen, "Casting the First Stone?" 
criticizes is, absent any evidence to the contrary, typically taken to be free of the relevant vices; for they present themselves as one who is capable of performing the speech act-one who is in a position to criticize.

Accordingly, moralizing will not always suffice to lay claim to moral authority. Certain kinds of disowning prefaces can remove the impression that one is actively invested in moral issues, or committed to particular values, among them: "Well, I'm not in a position to criticize him, but ...," and "Before I begin, I should specify that you ought to do as I say and not as I do." These prefaces can serve to blunt the force or status of the illocutionary act, perhaps rendering it an act of criticism rather than one of condemnation. ${ }^{16}$ The costs of moralizing thus go down; the speaker takes on less risk, and is exposed to lesser reproach. Typically, these prefaces also remove the impression that the speaker is disposed to act on their expressed moral opinions; for they suggest an absence of (or diminished) moral commitment.

A small but important clarification is needed here. We do not deny that those who are in "no position to criticize" can succeed in saying something that is both true and well-supported by reasons. ${ }^{17}$ Suppose that my friend criticizes me on account of my penchant for buying fur. She may be perfectly correct in thinking that I am to blame for my latest mink coat purchase. She might even cite the right sorts of reasons in support of her judgment. We should not swiftly infer from the many fur coats that adorn her wardrobe that this judgment is wrong or ill-supported. ${ }^{18}$ Her inconsistency suggests that we ought to question the strength of her moral commitments. But we should not necessarily question the content of her moral advice. (Though we may sometimes be indirectly justified in doing so-more on this in section 3.1.)

One may also take issue with another aspect of our story thus far: moral authority seems to come far too cheap. Perhaps we ought to refrain from investing others with any kind of trusted status prior to seeing them hard at work. A far more straightforward (and often far more costly) way to exhibit investment in moral issues is to take action. Surely we can often see the virtuous at work? We can, for instance, observe the religious leader as they shun the seductress, feed

One might want to claim that it is only the perlocutionary force of the utterance that is compromised; the condemnations are properly counted as condemnations, but the addressee will not feel their sting. (We thank an anonymous referee for suggesting this alternative way of looking at things.) Our arguments do not depend on going one way or the other. We thank an anonymous referee for raising this issue.

18 To do so would be to commit the ad hominem tu quoque fallacy; the mistake of inferring from an individual's shortcomings that her judgments must likewise be defective. For an edifying discussion of this tempting fallacy in relation to hypocrisy, see Aikin, "Tu Quoque Arguments and the Significance of Hypocrisy." 
the poor, and refuse lavish gifts. Perhaps so. But this cannot be the whole story. We cannot, after all, observe everyone all of the time. Constraints on time and resources mean that we often have to take people at their word. Absent any evidence to the contrary, then, we tend to grant them the benefit of the doubt; we assume that their moral pronouncements are more or less accurate reflections of what lies within.

Finally, one might worry that, far from earning an agent esteem, moralizing can often have exactly the opposite effect. The "pursed lipped prigs and professional offence-takers" of the world - those who "travel through life looking for things of which to disapprove"-are hardly liked, let alone turned to for guidance. ${ }^{19}$ Such persons seem likely to earn reputations as priggish, sanctimonious, and pompous fools - not moral authorities.

This worry mistakes the nature of moral esteem; we need not find someone personally likeable in order to look up to them as a moral agent. That said, the concern is not baseless. An agent is plausibly less likely to earn the status of a moral authority when their moralizing borders on fanaticism (though, no doubt, this does sometimes happen). Like the pursuit of happiness or spontaneity, then, we suspect that the explicit and intentional pursuit of moral authority often proves self-defeating-especially when it is not carried out with finesse and due caution.

\section{HYPOCRITES AS SELF-UNDERMINED MORAL AUTHORITIES}

We have devoted quite a bit of space to spelling out the notion of a moral authority. Our doing so was not without good reason, for we take this social standing to be central to the phenomenon of hypocrisy. Such thinking forms the basis of the proposal that we shall now proceed to develop. The account is especially well-suited to capture paradigmatic instances of hypocrisy. However, and as we explain, it easily generalizes to the smaller scale as well.

\subsection{The Account}

We begin by exploring the core features of paradigmatic instances of hypocrisy: the homophobic senator caught with his pants down in the men's room, the vocal PETA advocate who occasionally sneaks in some bacon, the corrupt priest, and the like. We take such cases to be prime candidates for exemplars. The agents involved are uncontroversially hypocrites, and they seem especially likely 
to attract opprobrium. To our minds, the features of primary importance in such cases are the following. ${ }^{20}$

First, these cases involve a characteristic sort of mismatch between an agent's behavior and their pronouncements; the hypocrite expresses an unfavorable moral opinion of some action, and is then caught performing that very same action. Second, the pronouncements in question tend to involve criticism. Typically, the hypocrite will blame others for the very vice of which they themselves are guilty. Third, the hypocrite occupies a trusted position, at least within a particular community, and with respect to a particular moral issue. And more often than not, that trust carries with it a firm expectation that they will not behave precisely as they do.

Finally, the hypocrite's inconsistency is taken to carry important implications not only for our estimation of them, but also for their terms of interaction with others. It is not merely that we doubt the hypocrite's integrity, or question their moral compass. We also tend to think that they are no longer warranted in relating to others on particular terms - in condemning certain kinds of behavior, for example. The hypocrite's inconsistency bears upon their status as a moral attester, and (as we explain shortly), it may sometimes undercut our reasons for trusting the soundness of their judgment as well. Though there are perhaps other hallmarks of hypocrisy, we expect that these features will be widely agreed upon, and, to our minds, they are of the most fundamental importance.

In light of these core features, our considered hypothesis is the following: paradigmatic hypocrites are persons who by mismatch between judgments and actions, have undermined any claim they have to act as a moral authority. In paradigmatic cases, the relevant individual was considered a moral authority by their community, but their actions are taken to suggest that the esteem and deference extended to them was not deserved.

To demonstrate, consider our PETA advocate. It is plausible that they function as a moral authority within the community of animal rights activists-helping encourage strong disapproval of the animal meat industry, clarifying which products are cruelty-free, and so on. Clearly, however, there is a mismatch between the advocate's pronouncements and their actions. (There is an obvious tension between forcefully campaigning against the meat industry and indulging in bacon.) Once this inconsistency is discovered, moreover, it can be expected to have important implications for their standing within the relevant community. Not only is esteem likely to be retracted, but others are also likely to feel that the

20 Keep in mind that we regard these as exemplary features; it is not our contention that each is necessary for hypocrisy more generally. 
PETA advocate is no longer warranted in condemning them for the occasional indulgence at the local steak house.

To be clear, none of this is to suggest that the PETA advocate's judgment is false. They may very well be correct; I may be vulnerable to legitimate moral criticism on account of supporting the meat industry. But it would seem that they are in no position to condemn me, given their own meat-eating habits. Of course, the PETA advocate may take themselves to have good all-things-considered reasons to criticize others, even if they lack the standing or entitlement to do so. (Even meat eaters with a vegetarian streak may think it worthwhile to inform others about the cruelty of the animal meat industry-perhaps even as they sit down to a steak dinner.) But for reasons spelled out above, it is debatable how edifying their message will be. More importantly, we think that they will only have relevant supporting reasons to fall back on as they make their case-not their warrant as a moral authority. ${ }^{21}$

The considerations above notwithstanding, it is not implausible that the PETA advocate's inconsistency does give us some reason to question the soundness of their judgment. Since they do not seem to take the cause sufficiently seriously, they may lose a certain measure of trust; perhaps they cannot be fully relied on to distinguish cruelty-free products from others. Or perhaps their failure to live up to their own moral standards should suggest to us that those standards are unacceptably over-demanding. ${ }^{22}$

Understanding cases of paradigmatic hypocrisy through the lens of moral authority can, we propose, illuminate their centrally important features. Our proposal nicely explains why paradigmatic hypocrites tend to be public figures; such persons are especially well-placed to earn our esteem and trust. (One would expect that they have also racked up their fair share of enemies along the way.) So it is likely to be especially infuriating (or especially satisfying, depending on one's perspective), when they fail to live up to their own lofty standards. Moreover, our account captures the sense in which a hypocrite's relations to others are transformed by their actions. These relations are, we propose, precisely their claim to moral authority; it concerns their esteemed status, together with their ability to fulfill the relevant sanctioning and adjudicatory roles.

Though our proposal is well-suited to accommodate such cases, one might worry that paradigmatic moral authorities are far too rare to account for wide-

21 We thank an anonymous referee for pressing us on this point.

22 Aikin, "Tu Quoque Arguments and the Significance of Hypocrisy," 166. Notice that neither of these inferences involves committing the ad hominem tu quoque fallacy. The inference from an individual's moral defects to the defectiveness of her moral views is indirect; it proceeds via (what we take to be) reasonable supplementing premises. 
spread claims about hypocrisy. But the core features that are distinctive of paradigmatic hypocrisy are, we suggest, present in more familiar cases as wellthough, as we will now explain, they are present to varying degrees.

First, consider the mismatch that is distinctive of hypocrisy. We have proposed that paradigmatic hypocrisy consists in a mismatch between an explicit judgment and an action. This is to be expected. Explicit judgments are, after all, the most straightforward and least costly way to exhibit an investment in moral issues, and actions are the most straightforward way to be caught out. But they are certainly not the only ways; other forms of inconsistency can and do arise. Sometimes hypocrisy seems to involve a mismatch between two or more judgments or two or more actions. If I campaign against factory farms while praising the nobility of dogfights, I am arguably a hypocrite. Similarly so if I donate to Médecins Sans Frontières while buying stock in military contractors, even if I make no statement about either. (The boundary between judgment and action can be fuzzy, of course. We think that this a further reason not to insist on a strict judgment-action mismatch for non-paradigmatic cases.)

Second, paradigmatic hypocrites engage in the very behavior that they criticize. Acts of hypocritical criticism are thus closer to the paradigm than acts of hypocritical praise. We suspect that this is owing to the fact that the former generally involve deliverances of blame. In comparison with praise, blame tends to be a far more "serious affair," and we are understandably more concerned about undeserved punishment than unmerited reward. ${ }^{23}$ However, mismatches involving praise can also attract charges of hypocrisy. The hawkish politician who dodged the draft or the environmentalist who praises fuel-efficient cars while driving a Hummer attract the charge of hypocrisy because of their failure to do the praiseworthy things that they encourage in others. The same may be true of the person who preaches the benefits of clean living and early morning exercise, but frequently skips their morning run to nurse a cruel hangover. ${ }^{24}$ Though these cases are perhaps less common, they also seem linked with the expectations to which moralizing gives rise. Moral authorities are assumed to practice what they preach, and preaching can take the form of praise as well as blame. Further, insofar as praise elevates the objects of praise above the masses, there is at least (what might be thought of as) a relative element of condemnation-the lazy slugabed may not be positively bad, but they could do better.

Third, paradigmatic hypocrites are paradigmatic authorities: community leaders, priests, and the like. But generally speaking, a hypocrite need not occupy any such role. We may very well take a close friend or a colleague to be guilty

23 Watson, "Two Faces of Responsibility," 283.

24 We thank an anonymous referee for the excellent example. 
of hypocrisy. On our understanding, however, the notion of a moral authority is sufficiently flexible to account for cases of the latter sort. Everyday hypocrites are likewise failed moral authorities - though their authority is of a more restricted kind.

Let us explain. Moral authority is, on our understanding, a variable and contextual affair. It is a standing that comes in degrees. Although paradigmatic moral authorities are community leaders, parents, and priests, any member of a moral community can set themselves up as a moral authority with more limited force or scope. And doing so need not be particularly difficult-moralizing can often suffice. In the film Mean Girls, when Gretchen tells Cady that "ex-boyfriends are just off-limits to friends" because "that's just, like, the rules of feminism," she lays claim to moral authority within a group of only four.

Moral authority is therefore partly a relational matter: you might be an authority relative to me given my loose ways, even though most people would outrank you in turn. Likewise, it is community-dependent: the owner of the local BDSM dungeon may be a moral authority about consent and negotiation, even if the community itself is marginalized. Moral authorities may therefore be orthogonal to traditional social hierarchies: the Solomonic bartender can be an authority despite his humble station. Finally, moral authority can be local to a particular issue. I might make for a fantastic moral authority when it comes to relationship advice, but a poor one when it comes to social justice. ${ }^{25}$

We are now in a position to apply our paradigm-based account to the smaller scale. It is our contention that more familiar cases of hypocrisy similarly involve a mismatch that serves to undermine an agent's claim to moral authority. But the moral authority in question need not be authority of the paradigmatic sort. Compare our PETA advocate with a friend who routinely condemns the animal meat industry and often boasts about their vegetarian lifestyle. Suppose that I happen to discover that this friend-who is all too keen to rebuke me for my trips to the local butcher-has a habit of indulging in bacon when the opportunity presents itself. Surely my friend is guilty of hypocrisy. And there is, we propose, a clear sense in which their moral authority with respect to animal rights issues has been undermined by their actions. That authority concerns, among other things, their capacity to fulfill the sanctioning role. To do so, they must be in a position to condemn me for consuming meat products. But they are surely in no such position if they are guilty of having done so themselves. The illo-

25 Our remarks here are somewhat reminiscent of an idea that is often raised in discussions of moral testimony. While it is controversial whether individuals can be moral experts tout court, it is generally accepted that they may claim expertise with respect to a specific moral issue (Hopkins, "What Is Wrong with Moral Testimony?" 623-26). 
cutionary force of their criticism certainly seems to have been blunted by their actions. Likewise, their authority concerns their ability to adjudicate edge cases: is the dairy industry just as cruel as the meat industry? I may in the past have trusted what my friend had to say on the matter. But my confidence in this testimony could very well be shaken by their inconsistency; for I may now suspect that they do not take the cause sufficiently seriously. ${ }^{26}$ It would also be understandable if I were moved to retract some of the esteem that I had previously extended to them on account of their vegetarian lifestyle.

Our proposal therefore seems especially well-placed to accommodate and shed light on core features of hypocrisy-among them, the significance of the mismatch between a hypocrite's pronouncements and their actions, and its implications for the terms of their interaction with others. Admittedly, these features are far more obvious and pronounced in paradigmatic cases: the moral authority is more extensive, the pronouncements usually take the form of harsh criticism, and the inconsistency tends to be especially infuriating. But the very same features seem to operate on the smaller-scale as well.

\subsection{Caveats and Clarifications}

Several features of our account are worth noting in detail. We begin by fleshing out the relationship between hypocrisy and failures of moral authority. Note that our formulation of hypocrisy is phrased in terms of claims to moral authority rather than actual moral authority. Thus, the account also covers cases in which someone has never actually played the role. My friend is a notorious philanderer. At the pub one evening, they criticize my infidelity. They are a hypocrite, of course, even if nobody was ever inclined to listen to them in the first place. The important thing is not that the mismatch undermines what authority they have, but what authority they might reasonably claim.

On our account, then, all hypocrites are persons who fail in laying claim to moral authority. But it does not follow that all who fail in laying claim to moral authority are hypocrites. An individual might fail in this regard simply by revealing themselves to be too confused or misinformed to count as an authority on a

One might worry that the account does not work quite as well when the moral stakes are low. Suppose that my friend chastises me for littering one day. The next day, they unceremoniously toss their soda can into the local river. Our account suggests that have undermined their authority on the ethics of littering. But that might strike one as slightly too strong. However, we think that such cases likewise involve an undermining of moral authority. My friend is surely no longer in a position to condemn me for littering if they are guilty of having done so themselves. Another way to assuage this concern (for those still unconvinced) is to note the possibility that when the moral stakes are low a hypocrite might be one whose claim to moral authority has been diminished rather than undermined. 
particular moral issue. Serious factual errors, for instance, can reasonably reduce our confidence in an individual's suitability for the status without being self-undermining in the way that is distinctive of hypocrisy.

One can also lack the status of a moral authority simply by being (or being considered) a very bad person. The bushranger who rampages across the land is not fit to be a moral authority because they are not trying to be moral in the first place. In order to function as a moral authority within a particular community, one must, at minimum, be considered a good person. ${ }^{27}$ And, in order for that status to be deserved, one must actually be a good person. The status of moral authority requires not merely goodness but reliable, trustworthy goodness. ${ }^{28}$ Hypocrisy represents a very particular way of going wrong with regard to this requirement, and it is this requirement at which charges of hypocrisy aim.

Indeed, we suspect that this is precisely why a single act is capable of undermining one's claim to moral authority. Moral commitment is not a choose-yourown-adventure type of affair. Moral matters are deeply important to us, and we expect others to treat them with due seriousness. When people exhibit an investment in moral issues, we expect them to follow through on their moral commitments, even (perhaps especially) when it does not suit them.

A further important clarification concerns the truth-conditions of hypocrisy attributions. Although our account makes central reference to the relationship between the hypocrite and the moral community in which they are embedded, this should not be taken to suggest that whether or not someone counts as a hypocrite is entirely a matter of what others happen to think of them. Whether or not someone is a hypocrite is determined by whether the relevant mismatch undermines their claim to moral authority. Certain kinds of inconsistency certainly do have this feature, and so constitute hypocrisy—the militant vegan sneaking bacon, for instance. But others do not. A kind of inconsistency is at play, for example, when an individual changes their moral views over time. Yet the mis-

The "considered" proviso is important; for it is surely possible for incredibly bad people to function as moral authorities - to garner esteem, earn the status of a trusted moral adviser, and so on. Indeed, we might even think that this is characteristic of the most spectacular cases of hypocrisy (those that typically make the headlines). But it is, at least to our minds, difficult to imagine those who are taken to be depraved, vicious, or cruel functioning as moral authorities (though they can of course function as authorities of some other kind-heartless tyrants who rule through fear, for instance). A converse, and more complicated, case is that of the "accidental sage" who is taken to be an authority for mistaken reasons (Chance the gardener, say). Again, the important thing is (we think) the way that they are perceived: the accidental sage is open to charges of hypocrisy, though in defense they will likely point out that they never took themselves to be giving moral guidance.

It is helpful to keep in mind here that (as was suggested earlier) "trustworthy goodness" will often be relative to a particular moral issue. 
match here does not necessarily undermine their claim to moral authority; for it might be representative of careful reconsideration of moral issues. Our account therefore makes room for the possibility that moral agents can be mistaken in their attributions of hypocrisy. Insofar as they are mistaken about the details of the case, they might be wrong in thinking that someone has done something to undermine their claim to moral authority.

Finally, one might worry that the hypocrite's undermining of their claim to moral authority is a consequence of their hypocrisy rather than constitutive of it. ${ }^{29}$ If this is so, then we have failed to deliver on our promise; far from providing an account of hypocrisy, we have merely provided an account of what follows from it.

We have a few things to say in response to this important challenge. To begin with, it is helpful to disambiguate two readings of the objection. On the first, the objector thinks that hypocrisy is constituted by something else (pretense or lying or what have you) and that this something else is what leads to the loss of moral authority. This form of the objection would require providing an alternative account of the nature of hypocrisy. We are obviously skeptical that such an account can be given. On the other hand, the objection could be that hypocrisy is something like a second-order property of actions: it is the property that actions have when they cause the hypocrite to lose moral authority. But the latter comes so close to our account that we confess that we can see little light between it and our own position.

The concern can be further alleviated by distinguishing two senses in which someone can be a moral authority. There is a distinction to be drawn between an agent's (1) being entitled to authority, and (2) actually being considered an authority by others. As in other realms, the two can come apart. We are concerned with the former: hypocrites undermine their claim to authority, but this may or may not be discovered. Cases in which an action alone is enough to undermine authority are comparatively rare outside of the moral domain, but only because we usually consider the removal of authority a subsequent act carried out by the body who grants it. But comparable cases do exist: a British monarch who converted to Catholicism, or a priest who violates the seal of confession, have by their act alone undermined their authority. ${ }^{30}$

29 We thank an anonymous referee for raising this important objection.

30 Note that in these cases the important thing is that the act is what constitutes the undermining of authority, even though the fact that that relation holds is ultimately dependent on external authority (respectively, the Act of Settlement and the canon law relevant to excommunication latae sententiae). 


\subsection{Advantages of the View}

Having spelled out the finer details of our account, we turn now to its advantages (many of which, we argue shortly, are distinct advantages).

First, our view explains why judgments of hypocrisy often have a certain "leaky" quality to them, and why the mismatch between judgment and action need not be direct. Consider a vegan who extols the environmental benefits of their diet, but is condemned as a hypocrite for not riding public transit. At first glance, their judgment and action concern quite different things. Yet the charge of hypocrisy is understandable if it is understood along the lines we have proposed-as a judgment that their transit choices undermine any claim they have to act as a moral authority on environmental matters in general.

Second, our account can accommodate cases in which mismatches involving praise attract charges of hypocrisy. On our view, a moral authority's status arises, in part, as a result of the link that others take to hold between their moral pronouncements and their behavioral dispositions. For this reason, an individual's failure to do the praiseworthy things that they encourage in others can easily undermine their moral authority, and so expose them to allegations of hypocrisy. ${ }^{31}$

Third, our account immediately makes clear why hypocrisy attracts such opprobrium. We place significant trust in moral authorities. But the promotion and consultation of moral authority is something of a fraught matter. Most of us save a certain amount of time and energy because moral authorities exist: our judgments can be accurate and more reliable, we spend less time on moral deliberation, and we take on less risk when we moralize. Yet moralizing is important, and errors are morally weighty. The errors of a moral authority matter more so than others, for they have broader and more wide-ranging consequences. Moreover, moral authorities acquire much of their standing on credit- that is to say, through their words rather than their actions. And this requires an additional level of trust on our part. When they fail, then, we have every right to feel hurt, betrayed, and angry. Indeed, we might dislike the hypocrite even if we never belonged to the community that they address (a point to which we return in section 5).

Once again, it is worth noting that not all forms of praise render one vulnerable to allegations of hypocrisy. As we suggested earlier, certain kinds of disowning prefaces can remove the impression that one's criticism is rooted in a deep-seated commitment to moral values. Some ways of lending praise can have parallel effects, and so may not invite charges of hypocrisy-presenting certain actions as laudable but supererogatory, for example. "If only we could be as pure as Saint Agnes!" sets up quite different expectations than "Everyone ought to be praised for chastity." 
In our view, however, it is not merely the element of betrayal or the risks to which they expose us that explain our contempt of hypocrites. We are also likely to be moved to anger by the unmerited esteem that they garner. Esteem is a good in high demand; we are usually happy to be esteemed by others, and we are more than happy to avoid their disesteem. ${ }^{32}$ But esteem, being inherently comparative, is a good in limited supply. We esteem those who score above average along some evaluative dimension, and not everyone can be above average. Since esteem is ultimately a zero-sum game, we invest moral authorities with our esteem at some cost to ourselves: by elevating them, we lose out a bit.

It is therefore unsurprising that hypocrites are traditionally met with disdain; for they have ultimately shown themselves to have been undeserving of this elevated status. Esteem is a sought-after and precious resource-one that we can earn through moralizing. Yet our moral words only buy us esteem for so long. Moralizing is not merely a matter of judgment; when push comes to practical shove, we must be prepared to perform those actions to which we have given praise and refrain from the sorts of behavior that we have criticized-even (or perhaps especially) if doing so would be inconvenient. Our moral pronouncements, then, have something like the status of a "buy now, pay later" scheme. Moral authorities enjoy the good of esteem without paying the costs up front. But eventually those costs must be paid, and they must be paid via action. In effect, hypocrites have purchased esteem, but failed to pay up when the time is right; they have, if you like, earned themselves a bad credit rating in the economy of esteem-something that is bound to attract a strong degree of moral opprobrium.

A fourth advantage of our account is that it does not explain this characteristic opprobrium by attributing any particular kind of deplorable character trait, unworthy motive, or cruel intentions to the hypocrite. On our view, hypocrites are simply persons who have, by mismatch (typically) between word and action, undermined their claim to moral authority. This formulation is permissive; it leaves the source of the mismatch entirely open. It might be explained by an intention to deceive or manipulate. Or it might be owing to an excessive concern with keeping up moral appearances. Each is surely a feature that some hypocrites share, and each may sometimes be helpful in explaining our characteristic dislike of them. But on our view, none is necessary. (We demonstrate the advantages of this permissiveness in section 4 ).

That said, a mismatch that finds its roots in deplorable motives may sometimes suffice. Our view has the resources to accommodate scheming hypo- 
crites. ${ }^{33}$ Consider Tartuffe, who pretends to be pious for reasons of self-advancement. His hypocrisy does not consist in a single bout of inconsistency (of the relevant sort), but in a rather extensive pattern of deception. Our account delivers the correct ruling here. Tartuffe is undoubtedly a hypocrite; for the mismatch between his pious pronouncements and his (very) impious motives and behavior surely does undermine his claim to moral authority. Our proposal can also explain why some may be inclined to judge Tartuffe more harshly than those whose hypocrisy is not so widespread; inconsistency as extensive as Tartuffe's would seem to undermine a purported claim to moral authority far more than a single moral lapse.

Finally, our account allows for extension of the concept of hypocrisy to groups. This is not uncommon. China accuses the United States of hypocrisy on human rights; the Labour Party charges Turnbull with hypocrisy in policy changes; activist Naomi Klein charges large corporations with hypocrisy about attitudes toward the environment. These charges are obviously intelligible, and a natural extension of ordinary hypocrisy. It is convenient to have an account that generalizes readily.

\section{THE MULTIPLE REALIZABILITY OF HYPOCRISY}

We now explore how well our account stacks up against its rivals. Most of these competing views, we suggest, are not so much wrong as incomplete. None succeeds in identifying necessary and sufficient conditions for hypocrisy. But each points toward a feature that can suffice to undermine authority in the right context, and that is common enough to deserve mention. Ultimately, we argue that what is plausible in these accounts can be subsumed under our own view.

\subsection{The Pretense Account}

It might seem characteristic of the hypocrite that they present themselves as something other than what they truly are. So it is perhaps unsurprising that the most common position regarding hypocrisy takes it to consist in a kind of deception; in pretending "to motives and moods" or to "certain standards" that one does not really have. ${ }^{34}$

Of course, the hypocrite's deception is thought to go in a particular direction. McKinnon emphasizes that the hypocrite "dissembles precisely because she wants people to think better of her than they would were her true motives 
revealed." 35 Szabados and Soifer's Aristotelian account similarly characterizes hypocrites as persons who do the right thing for the wrong reasons, all the while pretending that they are responsive to the right reasons. ${ }^{36}$ According to what we shall call the "pretense account," then, hypocrites are those who pretend to be far better than they really are.

Theorists divide regarding whether the deception here must be intentional. Hare seems to think so, as does McKinnon in early work. ${ }^{37}$ Others disagree. Statman, for instance, suspects that hypocrisy is incredibly likely to be the product of self-deception; insofar as the hypocrite seeks to cultivate a particular image in the eyes of others, the best means of achieving this might be to believe that image themselves. ${ }^{38}$ Some remain on the fence; although Szabados and Soifer take paradigmatic hypocrites to pretend to be virtuous for reasons of self-advancement, they concede that the deceit need not always be intentional. ${ }^{39}$ There is also some disagreement as to whether the pretense must be driven by self-interested concerns. Although the matter is often left open, some have answered in the affirmative. ${ }^{40}$

Pretense accounts capture something important about hypocrisy. After all, hypocrites often do portray themselves as exemplary moral agents, and often they are not. That being said, we have a number of worries with pretense accounts-particularly those that attribute deceptive intentions to the hypocrite. An intention to deceive does not appear to be a necessary condition on hypocrisy. It seems perfectly conceivable that someone could live out their days wholly unaware of any hypocrisy on their part. Following Statman, epiphanies of the form, "I suddenly feel that I have been a hypocrite all my life" do not seem to betray any sort of conceptual confusion. ${ }^{41}$ Moreover, and as R. Jay Wallace observes, some people are blind to their own shortcomings and do not foresee that they will fall short of their own moral standards in the future. ${ }^{42}$ But falling short

McKinnon, "Hypocrisy, with a Note on Integrity," 323; see also Kittay, “On Hypocrisy," 281. Szabados and Soifer, "Hypocrisy after Aristotle," 563.

7 Hare, Freedom and Reason, 77; McKinnon, "Hypocrisy, with a Note on Integrity," 323. McKinnon has since changed her mind, conceding that "there are many hypocrites who are quite unself-conscious about the extent to which they misrepresent their real reasons for acting" ("Hypocrisy and the Good of Character Possession," 719).

Statman, "Hypocrisy and Self-Deception," 68.

Szabados and Soifer, "Hypocrisy after Aristotle," 564.

See, e.g., McKinnon, "Hypocrisy and the Good of Character Possession," 722; Szabados, "Hypocrisy," 203.

1 Statman, "Hypocrisy and Self-Deception," 68.

2 Wallace, "Hypocrisy, Moral Address, and the Equal Standing of Persons," 315. 
of those professed standards would seem to expose them to the charge of hypocrisy all the same.

Another worry relates to the project of explaining why it is that hypocrisy typically strikes us as a deep and important species of moral failure. According to sponsors of the pretense account, this failure ultimately amounts to a form of deception. In leading others to (falsely) believe that they are moral paragons, hypocrites sever "the act from the intention," and misrepresent what they truly are. $^{43}$

But why think that deception about one's character constitutes a moral failing? The projection of a favorable self-image is arguably a pervasive phenomenon, at least on a small scale. Ordinary people tend to talk more about their charitable donations than their petty thefts, to cite workers' rights rather than aesthetic distaste when they refuse to shop at Walmart, or to pretty up their dating history for new partners. The desire to appear better than you are is so pervasive, and known to be so pervasive, that it is hard to see what is distinctively bad about it. ${ }^{44}$

Finally, a common theme running through pretense accounts is that hypocrites are motivated by self-interested concerns; they are "out to promote [their] own advantage at the expense of others," their concern being exclusively with their "moral image." ${ }^{45}$ Yet it seems that hypocrites can have noble motives. Consider the father who hides his smoking from his children, inveighing against the unhealthy habit out of concern for them. There is no reason to think that his motivation here is self-serving, at least in any obvious sense. Nonetheless, his children would seem right to accuse him of a hypocrisy, should they ever discover his hidden stash. ${ }^{46}$

Pretense theorists attempt to reconcile noble hypocrisy with their accounts in different ways. Szabados suggests that we construe the notion of "self-interest" more broadly, such that having "some personal stake" in the "project of pretence" suffices. ${ }^{47}$ We agree with Crisp and Cowton that this strategy confuses motiva-

43 Kittay, "On Hypocrisy," 285; McKinnon, "Hypocrisy and the Good of Character Possession," 725 .

44 Wallace notes that one could move from here to the claim that bourgeois life is simply shot through with hypocrisy ("Hypocrisy, Moral Address, and the Equal Standing of Persons," 312). We agree with him that this is a bit hysterical, and that another theory of hypocrisy is probably preferable. Szabados, "Hypocrisy," 203; McKinnon, "Hypocrisy and the Good of Character Possession," 722.

46 For discussions of noble hypocrisy, see Crisp and Cowton, "Hypocrisy and Moral Seriousness"; and Szabados, "Hypocrisy."

47 Szabados, "Hypocrisy," 204-5. 
tion and justification. ${ }^{48}$ Even if noble hypocrites derive some pleasure or benefit from behaving as they do, they may still act for other-regarding (as opposed to self-interested) reasons.

Unlike Szabados, McKinnon concedes that noble hypocrites act for other-regarding reasons. Yet she argues that we have good reason to distinguish such persons "from the hypocrite who is ashamed of her concealed motives or ... whose preoccupation is with her reputation rather than with any actual outcomes she could effect." ${ }^{\prime 9}$ We agree that there is an important distinction between individuals driven by morally laudable motives and those who have morally questionable intentions. (Blame, or harsh judgments about an agent's moral character, for instance, may not strike us as fully appropriate in the former case.) But we do not think that this is a distinction that marks off hypocrisy from the absence thereof. Since hypocrites can sometimes act from noble motives, we see no reason for thinking that it is a constraint on hypocrisy more generally that it must be driven by self-interested concerns.

\subsection{The Blame-Centered Account}

We turn next to R. Jay Wallace's account of hypocrisy, which emphasizes the role of reactive attitudes-blame in particular. ${ }^{50}$ It is worth noting from the outset that Wallace's explanatory ambitions are restricted in two important respects. First, he confines his explanandum to instances of hypocritical moral address: cases in which an agent is "actively exercised" about a moral issue. ${ }^{51}$ It is this particular form of hypocrisy that Wallace finds distinctively objectionable on moral grounds. Second, Wallace limits his investigation to the phenomenon of hypocritical moral criticism. He does not propose to offer an account of hypocritical moral advice, whereby an agent fails to follow her own moral recommendations.

According to Wallace, what is objectionable about hypocritical moral address is that it offends against "the commitment to the equality of persons that is constitutive of moral relations. ${ }^{52}$ We all share an interest in avoiding the punitive experience of blame. ${ }^{53}$ But the hypocrite would take their interest in avoiding blame to be more important than the interests of the person whom they criticize. So their hypocrisy effectively ascribes a moral standing to themselves that they

48 Crisp and Cowton, "Hypocrisy and Moral Seriousness," 348 n7.

49 McKinnon, "Hypocrisy, with a Note on Integrity," 325.

50 Wallace, "Hypocrisy, Moral Address, and the Equal Standing of Persons."

51 Wallace, "Hypocrisy, Moral Address, and the Equal Standing of Persons," 312.

52 Wallace, "Hypocrisy, Moral Address, and the Equal Standing of Persons," 308.

53 Wallace, "Hypocrisy, Moral Address, and the Equal Standing of Persons," 328-29. 
are unwilling to extend to others. It is because this offends against a central moral precept - that of the equal standing of persons - that Wallace regards hypocritical moral address as distinctively objectionable on moral grounds.

There is yet another way in which hypocritical moral address is thought to offend against the commitment to the equality of persons: the hypocrite also attaches greater importance to the interests of the criticized person's victims than the victims of their own moral transgressions. ${ }^{54}$ They blame someone for dishonesty while allowing their own dishonesty to remain unscrutinized, effectively demonstrating that they take that person's victims to have a more serious interest in avoiding dishonesty than the victims of their own dishonest conduct. Since a commitment to the equality of persons is central to moral thought, hypocritical moral address is said to offend "against the spirit of morality, subverting it ... from within." ${ }^{55}$

Wallace's account is insightful. It is one of few that does not specifically depend on attributing hidden agendas or deficiencies of character to hypocrites (e.g., an intention to deceive, or an excessive concern with one's moral reputation). Instead, Wallace focuses on the reactive attitudes that govern our interactions within a moral community, and construes hypocrisy as deriving from particular relations that we enter into with others.

Insightful as it is, the limited nature of Wallace's account is a serious shortcoming. Wallace tackles but one species of hypocrisy-hypocritical moral criticism - and the account seems difficult to extend to cases of hypocritical moral advice. If I praise the chaste while secretly living lasciviously, I am, it seems, just as much of a hypocrite as if I blame you for your sins. Yet there does not appear to be the same harms at play; only in the second instance have I had any sort of objectionable reactive attitude toward you. A substantive theory of hypocrisy ought to account for the wrongfulness of both, but Wallace's account only has the resources to explain the latter.

A further issue with Wallace's account concerns its emphasis on the victims of hypocrisy. According to Wallace, the hypocrite values the victims of their own hypocrisy less than the victims of others who engage in the same conduct. But it is surely possible that a hypocrite could be one who cares considerably more about their own victims. Consider the person who inveighs against cheating at cards, though does so themselves. Suppose that every time they cheat, they compensate their victims the exact amount extorted from them. Perhaps this person does not care at all about the victims of others' cheating, and merely harbors a 
special concern for their own victims. But they would seem to be a hypocrite all the same. ${ }^{56}$

Finally, Wallace's blame-centered account would seem to have difficulty accounting for the role that hypocrisy attributions play both within and across communities. Although this account works naturally for moral communities who think that people are fundamentally equal from a moral point of view, charges of hypocrisy arise even in societies with no such commitment. The seventeenth-century Catholic Church, for example, was hardly egalitarian-yet audiences at the time recognized Tartuffe as a hypocrite all the same. Hence, even people who are not committed to something like the equality of persons can clearly recognize and condemn hypocrisy. This is something that Wallace's account seems to have trouble accommodating.

The blame-centered account also struggles with cases that do not involve two people. As noted above, countries and organizations can accuse and be accused of hypocrisy. Yet it is not at all obvious that nations, corporations, and political parties have reactive attitudes, or that they are the proper targets of reactive attitudes, or even that they are capable of the kinds of propositional attitudes that Wallace's account requires. Some philosophers may think so, of course. But the fact of us hypocrisy does not seem like it should depend on philosophical claims about group attitudes. Claims of intergroup hypocrisy ought to be intelligible regardless of whether groups have the same sorts of attitudes as individuals.

\subsection{The Moral Seriousness Account}

Roger Crisp and Christopher Cowton understand hypocrisy as a failure to take morality seriously. ${ }^{57}$ The proposal certainly has some attraction. Like our own view, the "moral seriousness account" construes hypocrisy as multiply realizable; there are many ways in which someone can fail to take morality seriouslydoing so need not necessarily consist in pretense, or misplaced blame.

Although the moral seriousness account has some initial appeal, we are skeptical that a failure to take morality seriously is sufficient for hypocrisy. Avowed egoists openly profess not to take morality very seriously at all, but they surely do not count as hypocrites for that reason. ${ }^{58}$ Nor does a failure to take morality seriously seem necessary for hypocrisy. As Szabados and Soifer point out, many hypocrites take morality far too seriously. The fanatic who cannot possibly live up

58 Szabados and Soifer, "Hypocrisy after Aristotle," 562. 
to their over-demanding moral prescriptions would seem to take morality very seriously indeed. But they still strike us as a candidate for hypocrisy.

Finally, and as we have suggested already, hypocrisy can sometimes stem from noble motives. The father who hides his smoking from his teenage son does not seem to be playing fast and loose with morality. This is not lost on Crisp and Cowton. Their defense rests on there being a morally significant distinction between hypocritical acts and hypocrites. ${ }^{59}$ Their theory is only intended to apply to the latter; it is only the full-blown hypocrite who is flippant about morality.

Crisp and Cowton are certainly entitled to restrict their ambitions. However, we think that this is a notable shortcoming of their proposal. The moral seriousness account is unlikely to shed much light on everyday attributions of hypocrisy; for these certainly do not appear to be restricted to those with a settled disposition to take morality insufficiently seriously. Perhaps such dispositions are to be found in the likes of Tartuffe or Uriah Heep. But the hypocrites of fiction represent something of a limiting case. It seems implausible to us that hypocrisy as it operates in day-to-day life amounts to a full-fledged character trait. Following Shklar, few of us ordinary folk "have the resources to become self-aware, scheming, accomplished hypocrites like Uriah Heep." ${ }^{60}$ If one is to capture the broad and varied phenomenon of hypocrisy, restricting the explanandum to persons with a particular kind of deplorable character seems ill-advised. We often accuse otherwise perfectly nice people of hypocrisy. An adequate conception ought to be able to account for this more common and banal species of hypocrite with whom we interact.

\subsection{Many Ways to Fall}

The theories canvassed above represent a number of ways of explaining what is common to all instances of hypocrisy. But they suffer from serious shortcomings. We believe that the moral authority account can preserve what is attractive in these other views while avoiding their associated problems.

Pretense accounts have an obvious appeal. Hypocrites do, after all, tend to portray a favorable self-image that is misleading. So it is natural to think that the relevant vice is that of deceit or manipulation. However, this feature is certainly not present in all cases of hypocrisy and, to our minds, it is not what is of fundamental importance. What is more important, we think, is the unmerited esteem that hypocrites often garner. Typically, the hypocrite does not live up to their own lofty standards, and so we feel angry that we invested them with our 
esteem and trust. However-and importantly-a hypocrite need not earn esteem through purposefully engaging in any form of deception. Many hypocrites simply set the bar too high for themselves, and do not foresee that they will fall short of their own standards in the future.

That being said, our view is consistent with the possibility that some (even many) hypocrites harbor deceptive intentions. A hypocrite may very well make lofty moral pronouncements with the goal of portraying a favorable self-image; indeed, we suspect that these cases are likely to attract a special sort of opprobrium. It is one thing to extend esteem where esteem is not due-it is quite another to be conned into doing so.

Moreover, there are other ways to have bad motives, or even to do the right thing for the wrong reasons. The man who rebuffs the advances of a lover only because he wants to ensure that he can take over his father-in-law's business is not concerned with self-image per se, but there is enough of a mismatch between his motives and his behavior that, under the right circumstances, he can rightly be judged a hypocrite. Again, the point is that there is no particular bad set of motives necessary to undermine claims to authority. ${ }^{61}$

Our view can also preserve what is right in the blame-centered account. Wallace's primary focus is hypocritical moral criticism, which characteristically involves deliverances of blame. It is understandable that Wallace should want to focus on blame to the exclusion of praise. As we suggested earlier, blame may very well be a hallmark of paradigmatic hypocrisy. Blame is an especially unpleasant experience; none of us wants to be on the receiving end-least of all from those who are guilty of the very same vice. Nonetheless, hypocrisy issuing from praise is a very real phenomenon, and it is one that Wallace's account would seem to have trouble accommodating. We concede that these cases are likely to be less serious, and they are perhaps not quite as common. But they are no less real for that. So we regard it as a virtue of the moral authority account that it can accommodate hypocritical praise as well.

Unlike the blame-centered account, our view can also explain the role that hypocrisy attributions play within and across communities. Wallace's view has difficulty accounting for attributions of hypocrisy across communities (and within non-egalitarian ones). Our account can accommodate cases like state actors who may or may not be the appropriate targets of second-person reactive

61 See Robbie Fulks's song, "Doin' Right (for All the Wrong Reasons)"; at least one of the authors thinks that the narrator is a loathsome person but not a hypocrite. Evaluation of people who act rightly for the wrong sorts of reasons can be complex in more realistic cases; for an extended discussion of the problems of "unprincipled virtue," see Arpaly, Unprincipled Virtue. 
attitudes. On our view, to call the United States hypocritical for its foreign policy is not (necessarily) to resent the nation; rather, it is first and foremost to claim that the United States's high-handed pronouncements on foreign policy ought not to be taken seriously.

Finally, we think that Crisp and Cowton make progress in allowing that hypocrisy can be multiply realizable. ${ }^{62}$ And the common feature that they propose to identify - a failure to take morality seriously - is surely one that many hypocrites share. However, the moral seriousness account lacks the resources to accommodate hypocrites who act from noble motives. Doing so is important; for we often charge otherwise perfectly nice people with hypocrisy. Such allegations certainly do not seem restricted to those with a settled disposition to take morality insufficiently seriously. That some hypocrites might be driven by laudable motives is consistent with the moral authority account. One can judge that someone is not apt to serve as a moral authority with respect to a particular moral issue even if they are, generally speaking, a good person.

In this portion of the discussion, we have been concerned to argue for two claims. First, although no particular motive, lack of motive, or violation of any specific moral principle is necessary for hypocrisy, within context each can suffice when it results in a mismatch of the relevant kind. Second, our account can preserve the benefits of other views while avoiding their associated problems. The moral authority account construes hypocrisy as multiply realizable: a hypocrite is simply someone who has, through a mismatch of the relevant kind, undermined their claim to moral authority. That mismatch might be the product of cultivating an undeserved moral reputation, a lack of moral seriousness, or something else still—perhaps even good intentions, or overreaching moral ambition. Since our proposal is consistent with any of these motives, it preserves what is appealing in these other views. But it is not committed to taking any particular motive to be necessary for hypocrisy, and so it avoids their associated problems.

\section{HYPOCRISY AND MORALLY DIVERSE SOCIETIES}

We conclude by discussing the role that judgments of hypocrisy play in regulating our social lives. When we introduced the idea of moral authority, we noted that it was something of a double-edged sword. On the one hand, moral authority can be a good thing: skill and time are as unequally distributed in moral reasoning as they are in any other domain, and we are normally better off if we look up to people who are good at what they do. On the other hand, when moral

62 Crisp and Cowton, "Hypocrisy and Moral Seriousness." 
authorities are inept or malicious they can cause serious harm. So we have excellent reason to keep a close eye on them

However, it is not only our own moral authorities that we monitor. Many of those whom we charge with hypocrisy function as moral authorities within different communities. So it seems that we are equally (and perhaps even more) disapproving of hypocrites whom we have no need to trust. ${ }^{63}$ This may seem puzzling at first. If such persons were never moral authorities for us-if we never held them in high esteem, or followed their advice - then why ought their failures concern us?

We propose that there is another (perhaps more important) role that judgments of hypocrisy play in contemporary societies. One striking feature of modern society is that it is morally diverse: multiple communities disagree over pressing moral issues. Yet those with radically different views can converge on judgments of hypocrisy. Perhaps we disagree on the matter of homosexuality; I think it is perfectly fine, whereas you condemn it as sin. But we can both agree that the homophobic senator's bathroom dalliances are hypocritical, and that they have undermined their claim to moral authority by their actions. We can further agree that the senator's hypocrisy is reprehensible-even while disagreeing on whether their expressed opinions or their actions were the right ones. An interesting feature of hypocrisy ascriptions, then, is that they seem capable of cross-cutting communities.

It is for this reason that judgments of hypocrisy play an especially important role within morally diverse societies. As Wallace notes, it is often ineffective to try to sway the opposing side by appealing to the very values over which we disagree. ${ }^{64}$ A charge of hypocrisy, by contrast, points toward a kind of moral failure that ought to give our opponents pause independently of our disagreement over more substantive issues. This peculiar quality of hypocrisy has not gone unnoticed. Indeed, some have gone so far as to claim that a charge of hypocrisy is the "most effective verbal weapon" in a "world of ideological conflict and moral confusion." 65

Our account is particularly well placed to accommodate this interesting feature of hypocrisy. On our view, a charge of hypocrisy is, first and foremost, a charge directed at an agent's standing rather than a criticism of an isolated action. For this reason, different communities can converge in their judgments of hypocrisy in spite of their substantive disagreements over moral issues.

We suspect that this is one reason why hypocrisy strikes us as something

63 McKinnon, "Hypocrisy, with a Note on Integrity," 326.

64 Wallace, "Hypocrisy, Moral Address, and the Equal Standing of Persons," 307.

65 Shklar, "Let Us Not Be Hypocritical," 22-23. 
worth tracking. In a world of rampant moral disagreement, we have excellent reason to keep track of moral authorities that we do not regard as authorities as well as those we do. All things being equal, we might allow a certain amount of sloppiness in the authorities that we trust. But authorities who command the respect of large numbers of people with whom we disagree can be held to a stricter standard. Even if we do not take them seriously, by exposing their hypocrisy we may be able to convince others that they should not take them seriously either. ${ }^{66}$ A charge of hypocrisy can undermine the status that such persons have come to enjoy - something that can, in turn, remove some of the force and cohesion of a community that we take to be getting the moral facts wrong.

This might sound as if hypocrisy judgments are simply cynical or calculating. They can be. But the purpose of hypocrisy judgments is not just to give us another arrow in our quiver against the unrighteous. At the best of times, we suggest, hypocrisy ascriptions can have a softening effect on moral discourse. Fearsome and rigid individuals might serve as moral authorities. Yet they do so at a considerably greater risk: the more stringent one's judgments, the easier it is to fall astray.

A moral authority who tempers their judgments, by contrast, is far less likely to run afoul of their own prescriptions, and more likely to be met with tolerance and forgiveness when they do so. This observation dovetails nicely with our earlier discussion of disowning prefaces, which can blunt the force of one's criticism, and soften one's purported claim to moral authority in turn. In order to avoid exposing ourselves to the charge of hypocrisy, we must temper the vehemence of our judgment. Those who are morally inflexible and harsh are more likely to disappear from the moral scene when they inevitably fail to live up to their own standards.

Charges of hypocrisy, then, are not merely a means of regulating our own moral communities. On the whole and in the aggregate, they play an important role in regulating the relationships between communities as well. This suggests a more positive and less cynical diagnosis of the state of play. At the best of times, judgments of hypocrisy can have a moderating effect within morally diverse societies: they tend to weed out the extremes. Insofar as persons disagree over moral issues, and insofar as they continue to turn to moral authorities for guid-

This idea is reminiscent of what Aikin calls "is (he) or ea (she) quoque arguments," which appeal to the hypocrisy of some third party rather than that of one's interlocutor ("Tu Quoque Arguments and the Significance of Hypocrisy," 161). He proposes (and we agree) that such arguments are not necessarily fallacious. Insofar as an individual's hypocrisy provides us with some reason to question their sincerity or moral competence, it may provide us with reason to question the soundness of their advice as well. 
ance, judgments of hypocrisy might help us steer them in the direction of the relatively fair minded and tolerant ones. ${ }^{67}$

\author{
Australian National University \\ u5312691@anu.edu.au \\ Macquarie University \\ colin.klein@mq.edu.au
}

\title{
REFERENCES
}

Aikin, Scott F. “Tu Quoque Arguments and the Significance of Hypocrisy.” Informal Logic 28, no. 2 (2008): 155-69.

Arpaly, Nomy. Unprincipled Virtue. New York: Oxford University Press, 2003.

Boyd, Robert, Herbert Gintis, Samuel Bowles, and Peter J. Richerson. "The Evolution of Altruistic Punishment." Proceedings of the National Academy of Sciences 100, no. 6 (March 2003): 3531-35.

Brennan, Geoffrey, and Philip Pettit. "The Hidden Economy of Esteem." Economics and Philosophy 16, no. 1 (April 2000): 77-98.

Cohen, G. A. "Casting the First Stone: Who Can, and Who Can't, Condemn the Terrorists?" In Finding Oneself in the Other, 134-42. Princeton, NJ: Princeton University Press, 2012.

Crisp, Roger, and Christopher Cowton. "Hypocrisy and Moral Seriousness." American Philosophical Quarterly 31, no. 4 (October 1994): 343-49.

Dworkin, Gerald. "Morally Speaking." In Reasoning Practically, edited by Edna Ullmann-Margalit, 182-88. New York: Oxford University Press, 2000.

Estlund, David. Democratic Authority: A Philosophical Framework. Princeton, NJ: Princeton University Press, 2008.

Fricker, Miranda. "What's the Point of Blame? A Paradigm Based Explanation." Noûs 50, no. 1 (March 2016): 165-83.

Hare, R. M. Freedom and Reason. Oxford: Oxford University Press, 1963. Hopkins, Robert. "What Is Wrong with Moral Testimony?" Philosophy and Phenomenological Research 74, no. 3 (May 2007): 611-34.

67 Thanks to Edward Elliott, Nic Southwood, Lachlan Umbers, two anonymous reviewers, and audiences at the Australian National University and Macquarie University for helpful feedback on previous drafts. Special thanks to Esther Klein for feedback and debate over many years. Work on this paper was partly supported by Australian Research Council grant FT140100422 to Colin Klein. 
Kittay, Eva Feder. “On Hypocrisy." Metaphilosophy 13, no. 3-4 (July 1982): 27789.

Lenman, James. "Ethics without Errors." Ratio 26, no. 4 (December 2013): 391409.

Locke, John. Second Treatise of Government. 169o. Edited by C. B. Macpherson. Indianapolis: Hackett Publishing Company, 1980.

McKinnon, Christine. "Hypocrisy and the Good of Character Possession." Dialogue 41, no. 4 (Fall 2002): 715-39.

- "Hypocrisy, with a Note on Integrity." American Philosophical Quarterly 28, no. 4 (October 1991): 321-30.

Owen, G.E.L. "Logic and Metaphysics in Some Earlier Works of Aristotle." In Aristotle and Plato in the Mid-Fourth Century, edited by Ingeman During and G. E. L. Owen, 163-90. Göteborg, Sweden: Almqvist and Wiksell, 1960.

Ryle, Gilbert. The Concept of Mind. London: Hutchinson, 1949.

Schwitzgebel, Eric, and Joshua Rust. "The Moral Behavior of Ethicists: Peer Opinion." Mind 118, no. 472 (October 2009): 1043-59.

Shklar, Judith. "Let Us Not Be Hypocritical." Daedalus 108, no. 3 (Summer 1979): $1-25$.

Statman, Daniel. "Hypocrisy and Self-Deception." Philosophical Psychology 10, no. 1 (1997): 57-75.

Szabados, Béla. "Hypocrisy." Canadian Journal of Philosophy 9, no. 2 (June 1979): 195-210.

. "Hypocrisy, Change of Mind, and Weakness of Will: How to Do Moral Philosophy with Examples." Metaphilosophy 30, nos. 1-2 (January/April 1999): 60-78.

Szabados, Béla, and Eldon Soifer. "Hypocrisy after Aristotle." Dialogue 37, no. 3 (Summer 1998): 545-70.

Taylor, Gabriele. "Integrity." Proceedings of the Aristotelian Society, Supplementary Volume 55 (1981): 143-59.

Wallace, R. Jay. "Hypocrisy, Moral Address, and the Equal Standing of Persons." Philosophy and Public Affairs 38, no. 4 (Fall 2010): 307-41.

Watson, Gary. "Two Faces of Responsibility." In Agency and Answerability: Selected Essays, 260-88. Oxford: Oxford University Press, 2004. 